Miller, M. \& Moses, A.M. (1969) Chlorpropamide induced release of antidiuretic hormone in patients with diabetes insipidus (abstracts). Clinical Research, 17, 290.

Miller, M. \& Moses, A.M. (1970a) Potentiation of vasopressin action by chlorpropamide in vivo. Endocrinology, 86, 1024

Miller, M. \& Moses, A.M. (1970b) Mechanism of chlorpropamide in diabetes insipidus. Journal of Clinical Endocrinology, 30, 488.

Reforzo-Membrives, J., Moledo, L.J., Lanaro, A.E. \& Megias, A. (1968) Antidiuretic effect of 1-propyl-3-p- chlorobenzene-sulfonylurea (chlorpropamide). Journal of Clinical Endocrinology, 28, 332.

Silber, R.H. \& PoRTER, C.C. (1954) Determination of 17,21dihydroxy-20-ketosteroids in urine and plasma. Journal of Biological Chemistry, 210, 923.

Webster, B. \& BAIN, J. (1970) Antidiuretic effect and complications of chlorpropamide therapy in diabetes insipidus. Journal of Clinical Endocrinology, 30, 215.

Weissman, P.N., Shenkman, L. \& Gregerman, R.J. (1971) Chlorpropamide hyponatremia. New England Journal of Medicine, 284, 65.

\title{
Micro-angiopathic haemolytic anaemia associated with a giant haemangioma of the liver
}

\author{
M. Nanda Prematilleke \\ M.B.,B.S(Cey.), D.C.P.(Lond.), D.Path.(Eng.), M.R.C. Path.
}

\section{General Hospital, Kandy, Ceylon}

MiCRO-ANGIOPATHIC haemolytic anaemia is the term introduced by Brain, Dacie \& Hourihane (1962) to describe an unusual type of haemolytic anaemia found in association with thrombotic thrombocytopenic purpura, acute glomerulonephritis in infancy and childhood (haemolytic-uraemic syndrome), renal cortical necrosis, microscopic polyarteritis nodosa, some cases of malignant hypertension and carcinomatosis. The characteristic blood changes were the presence of contracted cells, triangular cells, burr cells, crenated cells and red cell fragments.

The association of similar haematological features with benign tumours has not been recorded. The present report records a case of micro-angiopathic haemolytic anaemia found in association with a giant haemangioma of the liver.

\section{Case report}

The patient, a 40-year-old Sinhalese housewife, was admitted to a surgical ward of the General Hospital, Kandy, Ceylon, on 19 September 1970, with a history of a painless lump in the abdomen of 13 years' duration, gradually increasing in size. Her bowels were regular. There was no history of having passed blood per rectum. There was no vomiting and no past history of jaundice. Her menstrual periods were regular. She had had seven pregnancies of which the first child is alive. All other pregnancies, except the second, ended in abortions between the third and the seventh months, the second being a premature delivery at 8 months, and the baby died on the eighth day. The cause of death was not known, but the baby was neither jaundiced nor oedematous. Four of the pregnancies occurred before the present illness. Six years ago, the patient had undergone a laparotomy in another hospital for the same complaint and a large haemangioma of the liver was detected but not excised.

On examination, the patient was afebrile. BP $120 / 75$. Heart and lungs were clinically and radiologically normal.

Her abdomen was grossly enlarged. There were dilated veins on the anterior abdominal wall, which drained from above downwards. There was a lump arising from under the right costal margin and extending about $35 \mathrm{~cm}$ down to the right iliac fossa. It was firm and nodular, its dullness on percussion being continuous with the liver dullness. There was a band of resonance across the lower part of the lump which on radiological examination was found to be the transverse colon pushed downwards by the lump. The spleen was $7 \mathrm{~cm}$ below the left costal margin, firm and non-tender. There was a little ascites.

Gynaecological examination revealed no abnormality in the uterus or the ovaries.

On radiological examination a large soft tissue tumour arising from the liver was seen. It showed patchy areas of calcification. The right kidney was occupying a position immediately to the left of the midline, while the left kidney was in its normal position. Both kidneys were found to function normally. Barium meal studies showed that the 
stomach was pushed to the left by a mass continuous with the liver shadow.

Investigations. $\mathrm{Hb} 8 \mathrm{~g} / 100 \mathrm{ml}$; PCV $30 \%$, MCHC $27 \%$, ESR $2 \mathrm{~mm} / 1 \mathrm{hr}$. The stained peripheral blood films showed anisocytosis and poikilocytosis with bizarre shaped red cells including burr cells, triangular cells, crenated cells and spherocytes (Fig. 1). There were also polychromatic cells and occasional normoblasts. Artefactual changes of red-cell shape in vitro were excluded by confirming these findings in wet films. WCC $4800 / \mathrm{mm}^{3}$ (neutrophils $56 \%$, lymphocytes $36 \%$, eosinophils $8 \%$ ). Platelet count varied from $72,000 / \mathrm{mm}^{3}$ to $105,000 / \mathrm{mm}^{3}$. Reticulocytes $4 \cdot 2 \%$. No Heinz bodies were seen. Bleeding time $4 \mathrm{~min}$. Whole blood clotting time $7 \mathrm{~min}$, but the clot was partial and a part of the blood remained fluid even after $20 \mathrm{~min}$. Prothrombin time done on several occasions varied from 18 to $21 \mathrm{sec}$, while the normal control was $14 \mathrm{sec}$. Plasma fibrinogen was less than $100 \mathrm{mg} / 100 \mathrm{ml}$ (normal $150-450 \mathrm{mg} / 100 \mathrm{ml}$ by the turbidimetric method (Wootton, 1964)). Fibrin degradation products could not te studied for lack of facilities. Stained smears of sternal marrow showed hyperplastic erythropoiesis with minimal iron stores. Alkali denaturation test gave normal results. Osmotic fragility test showed a mild increase of fragility. Coombs' direct and indirect tests negative; spectroscopic examination of the plasma showed a faint absorption band of haemoglobin.

Blood urea $29 \mathrm{mg} / 100 \mathrm{ml}$. Liver function tests gave the following results: serum bilirubin $0.8 \mathrm{mg}$ with $0.2 \mathrm{mg}$ direct-reacting bilirubin, total plasma proteins $7 \cdot 3 \mathrm{~g}$, albumin $4.6 \mathrm{~g}$, globulins $2.7 \mathrm{~g}$, thymol turbidity 1 unit, zinc sulphate turbidity 4 units, alkaline phosphatase $8 \mathrm{KA}$ units and SGOT 10 units. Serum cholesterol $100 \mathrm{mg} / 100 \mathrm{ml}$.

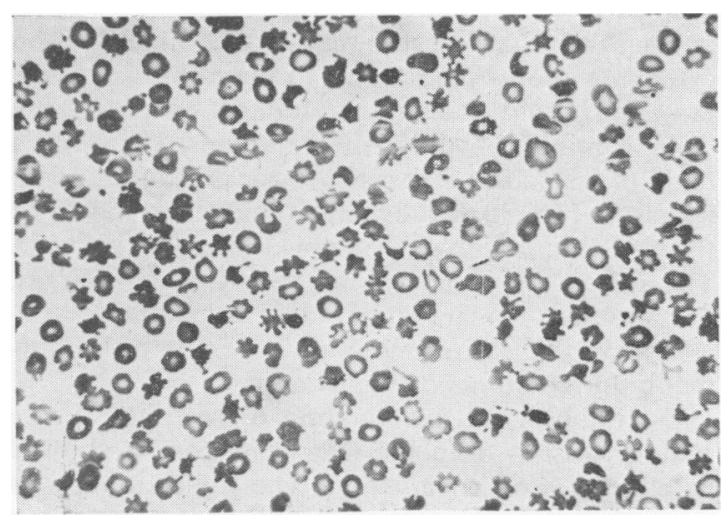

FIG. 1. Blood film showing irregularly contracted and crenated cells, burr cells, macrocytes and spherocytes. Leishman's stain, $\times 168$.

\section{Discussion}

The main haematological features in this case are anaemia with red-cell fragmentation and crenation, persistently low platelet count, low plasma fibrino- $\stackrel{\vec{S}}{\stackrel{D}{+}}$ gen, prolonged prothrombin time, pocr clot formation, trace of haemoglobin in the plasma and erythroid hyperplasia in the marrow. These findings conform to a diagnosis of micro-angiopathic haemolytic anaemia described by Brain et al. (1962). है Although several other workers such as Adelson, Heitzman \& Fennessey (1954) and Lock \& Dormandy (1961) have described similar blood pictures in various pathological states, they considered the red-cell changes to ke of varied aetiology.

Among the series studied by Brain et al., the 3 . presence of vascular lesions such as fibrinoid $\vec{\infty}$ necrosis of arterioles, evidence of necrotizing or

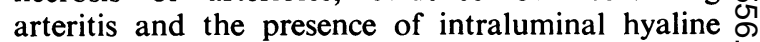
thrombi in arterioles and capillaries was a patho- $\vec{\exists}$ logical feature common to those who presented with $\overrightarrow{\vec{O}}$ overt haemolytic anaemia. Hence, they came to the $\frac{0}{2}$ tentative conclusion that the haemolysis in these cases may well be due to direct contact between $T$ patient's or transfused red cells and the altered intima of small vessels.

Later workers such as Brain \& Hourihane (1967 Brain, Esterly \& Beck (1967) and Rutenberg et at $\overrightarrow{0}$ (1968) produced similar haematological changes. N experimentally in rabbits by injecting endotoxing thrombin and the coagulant fraction of the venom of the Malayan pit viper Agkistrodon rhodostoma in each case, thus showing that intravascular coagulation in small vessels produced by whatever mechanism could result in red-cell fragmentation.

Bull et al. (1968) demonstrated in vitro the mechanism of red-cell fragmentation in micro-angiopathic haemolytic anaemia by perfusing blood at various speeds through a fibrin clot formed on a stainless steel perforated disc in a ring circuit.

The occurrence of red-cell fragmentation and intravascular haemolysis in association with intra- 3 vascular coagulation is thus well substantiated.

The presence of any of the diseases known to be associated with micro-angiopathic haemolytic anae- $\circ$ mia was excluded in our patient by clinical, laboratory and radiological examination. The only relevant $\frac{}{\mathrm{O}}$ pathological finding in her was a massive tumour of the liver which on previous laparotomy had been $\mathcal{N}$ found to be a haemangioma. No haematological $N$ studies had been done at the time of the laparotomy. N

Haemangiomas of the liver may be capillary or cavernous. They are usually under $2 \mathrm{~cm}$ in their largest dimension but occasionally they grow to a very large size (Wright \& Symmers, 1967). Fre- $\stackrel{\mathcal{Q}}{\rightarrow}$ quently numerous small capillary-like lumens are dispersed among the cavernous channels and there is in reality no sharp distinction between cavernous and 
capillary forms (Robbins, 1963). Thrombosis of the cavernous spaces and any stage of organization of the thrombi may be present. Some degree of fibrosis is usual and calcification can occur as was seen in our patient on radiological examination.

Considering the pathological anatomy of a haemangioma, it is possible to surmise that red-cell fragmentation could occur in such a situation as a result of coagulation in vascular channels especially when the tumour is very extensive.

\section{References}

Adelson, E., Heitzman, E.J. \& Fennessey, J.P. (1954) Thrombohemolytic thrombocytopenic purpura. Archives of Internal Medicine, 94, 42.

Brain, M.C., Dacie, J.V. \& Hourihane, D.O'B. (1962) Micro-angiopathic haemolytic anaemia: the possible role of vascular lesions in pathogenesis. British Journal of Haematology, 8, 358.

Brain, M.C., Esterly, J.R. \& BeCK, E.A. (1967) Intravascular haemolysis with experimentally produced vascular thrombi. British Journal of Haematology, 13, 868.
Brain, M.C. \& Hourihane, D.O'B. (1967) Micro-angiopathic haemolytic anaemia: the occurrence of haemolysis in experimentally produced vascular disease. British Journal of Haematology, 13, 135.

Bull, B.S., Rubenberg, M.L., DaCie, J.V. \& Brain, M.C. (1968) Microangiopathic haemolytic anaemia: mechanism of red-cell fragmentation in vitro studies. British Journal of Haematology, 14, 643.

LoCK, S.P. \& DoRMANDY, K.M. (1961) Red-cell fragmentation syndrome: a condition of multiple aetiology. Lancet, i, 1020.

RobBins, S.L. (1963) Textbook of Pathology with Clinical Application, 2nd edn, p. 468. W. B. Saunders, Philadelphia and London.

Rubenberg, M.L., Regoeizi, E., Bull, B.S., Dacie, J.V. \& BraIN, M.C. (1968) Micro-angiopathic haemolytic anaemia: the experimental production of haemolysis and red-cell fragmentation by defibrination in vivo. British Journal of Haematology, 14, 627.

Wootron, I.D.P. (1964) Microanalysis in Medical Biochemistry, 4th edn, p. 144. J. \& A. Churchill, London.

Wright, G.P. \& Symmers, W.ST.C. (1967) Systemic Pathology, 1st edn, Vol. 1, p. 664. American Elsevier Publishing Company, Inc., New York.

\title{
Autonomic dysfunction in syringomyelia
}

\author{
M. J. Aminoff \\ B.Sc., M.B., M.R.C.P. \\ C. S. WILCOX \\ M.A., B.M., M.R.C.P.
}

Department of Neurology, The Middlesex Hospital, London, W.1

SINCE the clinical syndrome of postural hypotension was first described by Bradbury \& Eggleston in 1925, numerous reports have appeared in the literature recording the association of this syndrome with disease of the nervous or endocrine systems. In this report, we describe a patient who developed autonomic dysfunction, with postural hypotension, in association with syringomyelia.

\section{Case report}

Mrs A.T., a 56-year-old housewife with syringomyelia was admitted to the Middlesex Hospital (No. G61625) under the care of Professor R. W. Gilliatt in April 1970, complaining of increasing weakness of the left leg.

The family history was non-contributory. The patient first noticed slight swelling and flexion deformity of the fingers of both hands at the age of 14 years and 2 years later found she could not feel heat normally with her hands. These symptoms gradually progressed and she noticed bruises and blisters on her hands, especially the left, from painless injuries and burns. At 25 years of age she developed weakness of the left arm and hand. She led an active life as a housewife until she was 50 years old, when her legs became weak. At this time she also developed urinary frequency, with nocturia, urgency, occasional urinary incontinence and less frequently faecal incontinence, without loss of bladder or rectal sensation. In the last 4 years she experienced several episodes of unsteadiness which were suggestive of postural hypotension as they occurred immediately after standing. She did not remember having sweated in hot weather for many years.

Examination revealed a dorsal kyphosis and scoliosis. There was no intellectual deficit and the cranial nerves were intact. In the arms there was wasting of the intrinsic muscles of both hands and of the left shoulder muscles, a painless arthropathy of the metacarpophalangeal joints of the right hand and clawing of the fourth and fifth digits of the left hand. Several scars from past injuries were present over both arms and hands. She had generalized weakness of the left arm with distal muscle weakness in the right arm, and loss of all tendon reflexes in the upper limbs. The abdominal muscles were weak and she was unable to sit up without support; the abdominal reflexes were absent. There was a spastic paraparesis 